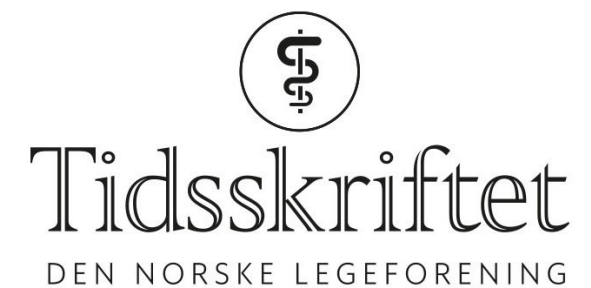

DEN NORSKE LEGEFORENING

\title{
Universitetene må rekruttere flere leger til basalmedisinske fag
}

DEBATT

\section{ERIK SVEBERG DIETRICHS}

E-post: erik.sveberg.dietrichs@uit.no

Erik Sveberg Dietrichs er ph.d., lege ved Universitetssykehuset Nord-Norge og førsteamanuensis og leder for forskningsgruppen for eksperimentell og klinisk farmakologi ved UiT - Norges arktiske universitet. Han er styremedlem i Foreningen for leger i vitenskapelige stillinger(LVS). Forfatteren har fylt ut ICMJE-skjemaet og oppgir ingen interessekonflikter.

\section{BENDIK CHRISTIAN BRINCHMANN}

Bendik Christian Brinchmann er ph.d., lege i spesialisering ved Statens arbeidsmiljøinstitutt og forsker ved Folkehelseinstituttet. Han er styremedlem i Foreningen for leger i vitenskapelige stillinger (LVS) og redaktør for LVS-info.

Forfatteren har fylt ut ICMJE-skjemaet og oppgir ingen interessekonflikter.

Hvorfor forsvinner leger fra basalmedisinske, akademiske stillinger ved universitetene? Medisinstudentene taper på at manglende satsing gjør universitetsstillingene til en lite attraktiv karriereveg for leger.

Medisinske basalfag utgjør en stor og viktig del av medisinutdanningen. Forståelse av basale mekanismer innen forskjellige fag som biokjemi, fysiologi og farmakologi er sentralt innen kliniske fagfelt. Det gir grunnleggende forståelse av sykdomsmekanismer og av hvordan fremtidige leger best kan behandle sine pasienter.

Da vi studerte i Troms $\emptyset$ og Århus for mindre enn ti år siden, var mange av foreleserne i basalfagene leger. Vi fikk også god undervisning av biologer og kjemikere, med inngående mekanistisk kunnskap, men legene satte stoffet inn i en klinisk kontekst.

Vårt inntrykk er at det ansettes stadig færre leger i professorater og amanuensisstillinger ved de norske universitetene. Fortsatt finnes det flere vitenskapelige ansatte leger innen basalfag, for eksempel ved Universitetet i Oslo, men vi er redde for at disse gradvis blir erstattet av akademikere uten medisinsk embetseksamen. Ved Institutt for medisinske basalfag er nå to av åtte professorater og amanuensisstillinger i biokjemi besatt av leger, mens det $\mathrm{i}$ andre basalfag som anatomi fortsatt er et flertall med legeutdanning.

Når Foreningen for leger i vitenskapelige stillinger (LVS) tar opp denne problemstillingen, blir vi ofte møtt med at det er mange kvalifiserte søkere til stillingene. De fleste medisinere har ikke like inngående basalkunnskap om et emne som realister med et fokusert utdanningsløp. Det er også vanskeligere å skrive og publisere artikler når man står i en klinisk eller paraklinisk utdanningsstilling. Likevel konkurrerer vi om de samme akademiske stillingene, fordi medisinsk embetseksamen eller klinisk erfaring sjelden er et 
krav. Paradoksalt nok er dette kvalifikasjoner som er helt sentrale i forelesningssalen. I møte med medisinstudentene er det ikke den mest inngående basalkunnskapen som er viktig, men den relevante basalkunnskapen og det å kunne sette den i et klinisk perspektiv.

Vi mener at undervisningen bør ha et translasjonelt fokus som viser sammenhengen mellom basale mekanismer og pasientens kliniske tilstand. Dette vil øke studentenes motivasjon for å lære basalfag, styrke legenes innsikt i grunnleggende mekanismer og på sikt komme pasientene til gode. Studentene må forstå hvordan og hvorfor stoffet er relevant når de står i akuttmottaket eller utreder pasienter med diffuse symptomer på legekontoret. Vi mener at dette perspektivet ofres under $\emptyset \mathrm{kt} \mathrm{krav} \mathrm{om} \mathrm{produksjon} \mathrm{av} \mathrm{undervisningstimer}$ for en stadig større masse av helsefagstudenter ved universitetene.

I møte med medisinstudentene er det ikke den mest inngående basalkunnskapen som er viktig, men den relevante basalkunnskapen og det å kunne sette den i et klinisk perspektiv

Vi mener at de økonomiske rammene for en translasjonell tilnærming til medisinsk vitenskap må styrkes. Det samsvarer med et internasjonalt fokus på at det translasjonelle potensialet i forskning og utdanning må verdsettes i langt større grad. En nylig publisert kommentarartikkel i Nature påpeker at akademikere med translasjonell innsikt må lede denne utviklingen (1). Et slikt fokus er etterspurt i utdanningen av forskere som skal finne nye legemidler (2). Nye, effektive behandlingsstrategier kan ikke utarbeides uten en rød tråd $\mathrm{i}$ arbeidet som skjer, helt fra laboratoriebenken til medikamentet blir gitt ved en sykehusavdeling. Skal vi henge med i utviklingen, som aktualiseres av den pågående pandemien, må vi også rekruttere flere leger til de basalmedisinske fagene ved norske universiteter.

Tidligere var en akademisk karriereveg både prestisjetung og attraktiv for medisinstudenter og leger. En amanuensisstilling eller et professorat innen medisin henger fortsatt høyt, men sammenlignet med sykehusstillinger er universitetsstillingene lavt lønnet. Klinisk spesialistkompetanse innen relevant fagfelt i en stilling ved universitetene gir heller ikke lønnsuttelling, i motsetning til en publikasjonsliste med lengde tilsvarende professorkompetanse. Helseforetakene lønner derimot forskende leger bedre, ofte uten de samme krav til tidkrevende undervisningsoppgaver.

Vi mener at manglende satsing og verdsetting av klinisk kompetanse gjør universitetsstillingene til en stadig mindre attraktiv karriereveg for yngre leger. Vi ser et system der medisinstudentene er avhengige av idealister for å få best mulig undervisning $\mathrm{i}$ basalmedisinske fag. En naturlig konsekvens er at kvaliteten på medisinstudiet blir dårligere. Dette vil forplante seg til klinikken og få konsekvenser for kvaliteten på utredning og behandling av pasientene. Vi mener derfor at det må iverksettes tiltak for å forbedre rekrutteringen av leger til vitenskapelige stillinger. At man ved de basalmedisinske instituttene har leger med sterke fagkunnskaper og gode formidlingsevner, er en forutsetning for å gi medisinstudentene den undervisningen de fortjener.

\section{LITTERATUR:}

1. Ogier R, Knecht W, Schwab ME. Academic leadership: (with)holding the keys to translational medicine? Nat Med 2019; 25: 1812-3. [PubMed][CrossRef]

2. Shahzad A, Cohrs RJ, Andersson R et al. Recommendations for comprehensive translational medicine education and training. Transl Biomed 2011; 2: 1-3.

Publisert: 26. januar 2021. Tidsskr Nor Legeforen. DOI: 10.4045/tidsskr.20.0918

Mottatt 11.11.2O2O, første revisjon innsendt 21.12.2020, godkjent 4.1.2021.

(C) Tidsskrift for Den norske legeforening 2020. Lastet ned fra tidsskriftet.no 